\title{
Challenging Behaviors in Young Children: The Role of Parenting Consistency in a Multigenerational Family
}

\author{
Maria Angela Andriono and Agnes Maria Sumargi \\ Faculty of Psychology \\ Universitas Katolik Widya Mandala Surabaya
}

\begin{abstract}
This study aimed to examine differences in challenging behaviors between young children in multigenerational families whose caregivers had consistent and those with inconsistent parenting. Participants were 73 pairs of mothers and grandparents who had children between the age of 2-6 years old in Surabaya and Sidoarjo. Purposive sampling was used to select participants and two scales included were the PSDQ (Parenting Styles and Dimensions Questionnaire) and CAPES (Child Adjustment and Parent Efficacy Scales). A one-way ANOVA was performed to compare children's challenging behaviors between caregiver groups with consistent-effective parenting, consistent-ineffective parenting, consistent-somewhat effective parenting, inconsistentineffective parenting, and inconsistent-somewhat effective parenting. Results showed that there was a significant difference of children's challenging behaviors at the $p<.05$ level for the five groups $[F(4.68)=5.73 ; p=.00]$. Compared to other parenting styles, caregivers with consistent-effective parenting had children with the lowest level of challenging behaviors.
\end{abstract}

Keywords: parenting consistency, challenging behavior, early childhood, multigenerational families

Penelitian ini bertujuan untuk menguji perbedaan perilaku bermasalah antara anak usia dini dalam keluarga multigenerasi yang pengasuhannya menerapkan pengasuhan secara konsisten dan tidak konsisten. Partisipan yang terlibat berjumlah 73 pasangan pengasuh (ibu dan kakek/ nenek) yang memiliki anak dengan rentang usia 2-6 tahun di wilayah Surabaya dan Sidoarjo. Pengambilan data dilakukan dengan cara purposive sampling dengan menggunakan alat ukur PSDQ (Parenting Styles and Dimensions Questionnaire) dan CAPES (Child Adjustment and Parent Efficacy Scales). Teknik ANAVA satu jalur digunakan untuk menguji perbedaan perilaku bermasalah pada anak usia dini antara pengasuhan konsisten-efektif, konsisten-tidak efektif, konsisten-agak efektif, tidak konsisten-tidak efektif, dan tidak konsisten-agak efektif. Hasil penelitian ini membuktikan adanya perbedaan perilaku bermasalah yang signifikan pada level $p<.05$ di antara lima kelompok pengasuh $[F(4.68)=5.73 ; p=.00]$. Dibandingkan pola pengasuhan lainnya, pengasuhan konsisten-efektif menunjukkan tingkat perilaku bermasalah yang terendah.

Kata kunci: konsistensi pola pengasuhan, perilaku bermasalah, anak usia dini, keluarga multigenerasi

Child behavioral and emotional problems usually occur in early childhood (Gardner \& Shaw, 2008). Parents often ignore the problems and think that their child will outgrow them or that behavioral problems in children are common (Campbell, Shaw, \& Gilliom, 2000). While a substantial number of children will outgrow these problems, there are some children who will continue showing challenging behaviors at school

Correspondence concerning this article should be addressed to Agnes Maria Sumargi. Faculty of Psychology, Universitas Katolik Widya Mandala Surabaya. Jalan Kalisari Selatan No.1 Surabaya 60112. E-mail: agnesmariasumargi@yahoo.com age and this may negatively impact their developmental process. A longitudinal study indicated that $50-60 \%$ of children showing high rates of behavioral and emotional problems at the age of 3-4 years continued showing the same problems at school age (Campbell et al., 1982; Campbell et al., 1996; Campbell et al., 2000, \& Richman, Stevenson, \& Graham, 1982 in Gardner \& Shaw, 2008). In addition, children with behavioral and emotional problems are more likely to be involved in juvenile delinquency and commit criminal acts and violence during adulthood (Farington, 1997, in Liu, 2004). Further, children with emotional 
problems are more likely to develop depression and anxiety (Liu, 2004).

The risk factors for challenging behaviors in young children can be categorized into biological and environmental factors. Examples of biological factors are individual differences in child characteristics, such as temperament and examples of environmental factors are family and parenting style (Gardner \& Shaw, 2008; Kaiser \& Raminsky, 2017).

Parenting style is an important component in child developmental process that can influence child behavior. Parenting style is defined as a series of parental efforts to control and socialize their child that can be categorized into three different types: authoritative, authoritarian, and permissive parenting (Baumrind, 1967, in Akhter, Hanif, Tariq, \& Atta, 2011). Each parenting style has different characteristics. Authoritative parenting is a parenting style in which parents encourage their children to be independent, responding to their needs but still set limits and control their behavior. This parenting style has been considered to be the most effective parenting style in developing children's positive behavior (Lamborn, Mounts, Stenberg, \& Dornbusch, 1991; Steinberg et al., 1994, in Akhter et al., 2011). Meanwhile, authoritarian parenting is characterized by a restrictive and punitive approach in which parents force their children to give respect and follow orders (Santrock, 2002). This parenting style has been considered to be the most negative and ineffective parenting style (Baumrind \& Black, 1967, in Akther et al., 2011). Permissive parenting is a style of parenting in which parents exhibit high levels of warmth and low levels of control over their children (Baumrind \& Black, 1967, in Akhter et al., 2011). Research has found that this style of parenting is associated with lower achievement and self-control, lower independence, as well as impulsive behavior in children, even it can foster more serious problems in adolescents, such as substance abuse and deviant behavior (Baumrind, 1967; McCord, 1988, in Akhter et al., 2011). Therefore, permissive parenting is considered to be an ineffective parenting style. Research showed that authoritarian and permissive parenting had positive correlations with child behavioral and emotional problems. In contrast, authoritative parenting had a negative correlation with child behavioral and emotional problems (Akhter et al., 2011).

Besides parenting styles, another risk factor for children's challenging behavior is family. A nuclear family is considered to be the ideal form of a family that can support children's growth and development (Simón, 2011). A nuclear family is a family unit that consists of parents and their children (Hoyer, Roodin, $\&$ Rybash, 1999). In this type of family, mothers are expected to stay at home and take care of their children, while fathers work outside home to earn their living. However, there is a large shift and new trend for family in recent years where mothers also work outside home, making them unable to rear their children and therefore, needing an assistance from other caregivers. One of the most trusted parties who can help with childcare is grandparents (Hoyer et al., 1999). Parents often consider their parents (hereafter called as grandparents) the most trustworthy caregiver whose care is believed to positively influence their child development (Greenblat \& Ochiltree, 1993; NICHD, 1996 in Ochiltree, 2006). For this reason, numerous children live in multi-generational families. A multigenerational family is defined as a family consisting of three generations or more who live together under the same roof. The generations are grandparents (first generation), parents (second generation) and children (third generation). The number of children that lives in multigenerational families has increased each year. The Pew Research Centre released a report indicating that in 2014, 60.6 million or $19 \%$ of people in the United States lived in multigenerational families. This number had increased compared to that in the year of 2000, where multigenerational families were only $15 \%$ of the population (Cohn \& Passel, 2006). There has been a limited report on the number of multigenerational families in Indonesia. Based on demographic information of 210 parents residing in Indonesia, Sumargi, Sofronoff, and Morawska (2015) found that $27 \%$ of parents reported that they lived with their extended families (multigenerational families). Furthermore, $37 \%$ of parents (62 out of 168 parents) reported that grandparents are the ones who take care of their children when they work.

Grandparenting may have a positive impact on children's life. Cooksey (1991, in Shimoni \& Baxter, 2005) indicated that grandparents play a significant role in this rapid development of the world by sharing family history and teaching about family traditions. Children living with their grandparents also tend to be more realistic with their life and perceive that aging is not something to be afraid of. However, there is also a negative impact of being raised by grandparents. A comparison study involving 54 African-American children who were raised by their grandparents and 54 children who were raised by their parents showed that those who were raised by their grandparents had more significant behavioral and emotional pro- 
blems than the children who were raised by their parents (Edwards, 2006). A qualitative study by Hartina, Fachrina, and Elvawati (2014) with eight grandmothers and one grandfather in West Sumatera found similar results. The study suggested that children who were raised by their grandparents were more likely to have challenging behavior, such as arguing, lying, and being lazy. The challenging behavior might be the result of permissive parenting style employed by their grandparents.

A preliminary interview with a teacher, a mother, and a grandmother of a child aged four years old living in a multigenerational family revealed a similar situation. The child showed behavioral problems at school, such as a lack of independence. He usually sought his grandmother when working on difficult tasks at school. He also failed to complete school tasks while other students did their tasks independently. The child also showed challenging behavior at home, such as shouting at his parents, whining, and refusing to eat food that is not his favorite food. In addition to behavioral problems, his mother and grandmother reported indications of emotional problems, such as being oversensitive and repressing feelings.

The occurrence of challenging behavior of children in multigenerational families might be related to conflicts between mothers and grandmothers (Barnett, Mills-Koonce, Gustafsson, \& Cox, 2012). Parenting young children can be difficult, particularly when there are more than one child caregiver such that in a multigenerational family. Conflicts between caregivers (mothers and grandparents) might be due to parenting differences (Clarke, Preston, Raskin, \& Bengston, 1999). Ochiltree (2006) suggested that differences in parenting practices between grandparents and parents are related to differences in disciplining children where grandparents seem to be more permissive than parents, thus indulging their grandchildren more often than setting boundaries. There-fore, parenting consistency between caregivers can be a major obstacle in a multigenerational family.

Parenting consistency means that both parents and the other child caregivers act together and respond to the child in similar ways, particularly when the child misbehaves or makes a mistake (Grose, 2011). Parenting inconsistency between caregivers might affect children's behavior. When parents and grandparents are inconsistent, what is deemed as acceptable behavior becomes unclear, and children eventually adopt double standards which they can strategically apply to different situations (Dowling, 2010). This is clearly seen from the preliminary interview, a mother reported that her child usually obeyed his grandmother, but he often shouted at and ignored his parents.

Based on the explanations above, it can be concluded that parenting consistency between caregivers is one of the factors that might affect challenging behavior of children in early childhood. In Indonesia, there has been no research that examines the role of parenting consistency between caregivers in a multigenerational family in relation to children's challenging behavior. It is, therefore, interesting to test diffrences in challenging behavior between young children in multigenerational families whose caregivers had consistent and inconsistent parenting.

This study was expected to benefit caregivers (parents and grandparents) and schools. Parents and grandparents would have a better understanding regarding the role of parenting consistency in young children's challenging behavior, thus raising awareness of the importance of parenting consistency between child caregivers. With the increased awareness, parents and grandparents could take preventive and curative actions for children's challenging behavior by employing effective and consistent parenting styles. This study would also provide information for teachers or early childhood educators about the importance of working together with child caregivers (parents and grandparents) in preventing and managing child's challenging behavior.

It was hypothesized that there were differences in the levels of challenging behavior between young children in multigenerational families whose caregivers had consistent and those with inconsistent parenting. Children's challenging behavior would be at the lowest level if they had caregivers with consistent and effective parenting.

\section{Method}

\section{Participants}

Participants were 73 pairs of mothers and grandparents who had children between the age of 2-6 years and lived together under the same roof (a multigenerational family) in Surabaya and Sidoarjo.

Demographic characteristics of participants (mothers and grandparents) are summarized in Table 1 . There were more grandmothers $(84.9 \%)$ than grandfathers who participated in this study. The mean age of mothers were $33(S D=7.9)$ and the mean age of grandparents were $61(S D=14.1)$. Participants had different educational levels. More than a half of mothers had completed an undergraduate degree at 
Table 1

Demographic Characteristics of Participants

\begin{tabular}{|c|c|c|c|c|c|}
\hline \multirow{2}{*}{ Characteristics } & \multirow{2}{*}{ Subgroup } & \multicolumn{2}{|c|}{ Mothers } & \multicolumn{2}{|c|}{ Grandparents } \\
\hline & & $n$ & $\%$ & $n$ & $\%$ \\
\hline \multirow[t]{2}{*}{ Gender of grandparents } & Female & - & - & 62 & 15.1 \\
\hline & Male & - & - & 11 & 84.9 \\
\hline \multirow{11}{*}{$\begin{array}{c}\text { Age } \\
\text { (years old) }\end{array}$} & $25-30$ & 13 & 17.8 & - & - \\
\hline & $31-35$ & 31 & 42.5 & - & - \\
\hline & $36-40$ & 24 & 32.9 & - & - \\
\hline & $41-45$ & 2 & 2.7 & - & - \\
\hline & $51-55$ & - & - & 9 & 12.3 \\
\hline & $56-60$ & - & - & 18 & 24.7 \\
\hline & $61-65$ & - & - & 16 & 21.9 \\
\hline & $66-70$ & - & - & 16 & 21.9 \\
\hline & $71-75$ & - & - & 9 & 12.3 \\
\hline & $76-80$ & - & - & 1 & 1.4 \\
\hline & Not mentioned & 3 & 4.1 & 4 & 5.5 \\
\hline \multirow[t]{7}{*}{ Educational level } & Primary school or lower & 1 & 1.4 & 5 & 6.8 \\
\hline & Junior high school & 1 & 1.4 & 16 & 21.6 \\
\hline & Senior high school & 16 & 21.9 & 36 & 49.3 \\
\hline & Diploma & 9 & 12.3 & 6 & 8.2 \\
\hline & Undergraduate degree & 43 & 58.9 & 6 & 8.2 \\
\hline & Postgraduate degree & 3 & 4.1 & 1 & 1.4 \\
\hline & Not mentioned & - & - & 3 & 4.1 \\
\hline \multirow[t]{5}{*}{ Employment status } & Full-time & 34 & 46.6 & 11 & 15.1 \\
\hline & Part-time & 9 & 12.3 & 8 & 11.0 \\
\hline & Freelancer & 3 & 4.1 & 6 & 8.2 \\
\hline & Not working & 27 & 35.6 & 45 & 61.6 \\
\hline & Not mentioned & 1 & 1.4 & 3 & 4.1 \\
\hline \multirow{8}{*}{$\begin{array}{l}\text { Time duration with the child } \\
\text { (hours per day) }\end{array}$} & $1-4$ & 13 & 17.9 & 11 & 15.0 \\
\hline & $5-8$ & 12 & 16.4 & 18 & 24.6 \\
\hline & $9-12$ & 12 & 16.4 & 19 & 26.0 \\
\hline & $13-16$ & 7 & 9.6 & 4 & 5.5 \\
\hline & $17-20$ & 6 & 8.2 & 1 & 1.4 \\
\hline & $21-24$ & 15 & 20.5 & 9 & 12.3 \\
\hline & Uncertain & 1 & 1.4 & - & \\
\hline & Not mentioned & 7 & 9.6 & 11 & 15.1 \\
\hline
\end{tabular}

university (58.9\%), whereas most grandparents were high school graduates (49.3\%). Most mothers worked full-time (46.6\%) and spent an average of 12.5 hours per day $(S D=8.0)$ with their child, whilst most grandparents did not work $(61.6 \%)$ and spent an average of 8.8 hours per day $(S D=7.4)$ with their grandchild.

Table 2 shows the child's characteristics as reported by mothers and grandparents. The proportion of girls $(50.7 \%)$ and boys $(47.9 \%)$ in this study were almost equal. The child mean age was $4(S D=0.96)$. Most children were in the first year $(46.6 \%)$ and second year of kindergarten (35.6\%).

\section{Measures}

The Family Background Questionnaire (FBQ) was used to collect information about participants' family backgrounds (Sumargi et al., 2015). Data collected were the age of caregivers and children, their educational levels and employment status, the number of hours spent with the child, and family structure indicating whether they stayed as an original family or a multigenerational family.

Parenting consistency was measured using the short version of Parenting Styles and Dimensions 
Table 2

Demographic Characteristics of Participants Based on the Child's Characteristics

\begin{tabular}{llcc}
\hline \multicolumn{1}{c}{ Characteristics } & & Mothers \& \\
& & Subgroup & Grandparents \\
& & & $\%$ \\
\hline Age of the child & 2 & 2 & 2.7 \\
(years old) & 3 & 11 & 15.1 \\
& 4 & 32 & 43.8 \\
& 5 & 25 & 34.2 \\
& 6 & 2 & 2.7 \\
& Not mentioned & 1 & 1.4 \\
Gender of the child & Male & 35 & 47.9 \\
& Female & 37 & 50.7 \\
& Not mentioned & 1 & 1.4 \\
Educational level of the & Early childhood education programs (PAUD) & 1 & 1.4 \\
child & First-year preschool (playgroup A) & 5.5 \\
& Second-year preschool (playgroup B) & 4 & 8.2 \\
& First-year kindergarten (A) & 6 & 46.6 \\
& Second-year kindergarten (B) & 34 & 35.6
\end{tabular}

Questionnaire (PSDQ; Robinson, Mandleco, Olsen, \& Hart, 2001). The measure had been translated into Indonesian by the second author and back translated. The short-version of PSDQ consists of 32 items reflecting three different parenting styles: authoritative parenting (15 items), authoritarian parenting (12 items), and permissive parenting (five items). Each item has a 5-point scale, ranging from 1 (Never) to 5 (Always). The reliability coefficients of the Indonesian version of PSDQ has been reported good for authoritative and authoritarian parenting $(\alpha=.88$ and $\alpha=.79$, respectively) but poor for permissive parenting $(\alpha$ $=.49$; Haslam, Poniman, Filus, Sumargi, \& Boediman, 2018). In this study, the reliability coefficients were .85 (mothers) and .91 (grandparent) for authoritative parenting, .79 (mother) and .77 (grandparent) for authoritarian parenting, and .56 (mother) and .43 (grandparent) for permissive parenting.

Three separate scores representing authoritative, authoritarian, and permissive parenting were calculated for each participant. Participants were then grouped based on the parenting styles used most frequently. Each participant's individual score was compared with the mean score of each parenting style. A higher individual score indicated that participants employed a particular parenting style more often than the other parenting styles. Notably, it was possible that a participant had more than one dominant parenting style or no dominant parenting style. We excluded pairs of participants who had no dominant parenting style. In the next step, a mother's parenting style was compared with a grandparent's parenting style. If the parenting styles of a mother and a grandparent were the same, then the pair was considered to have a consistent parenting. However, if their parenting styles were different, then they were considered to have an inconsistent parenting. In addition to parenting consistency, we also took into account parenting effectiveness. The parenting literature has indicated the positive impacts of authoritative parenting and the negative impacts of authoritarian and permissive parenting on child's behavior. In other words, authoritative parenting is considered more effective than the other parenting styles (i.e., non-authoritative parenting). Thus, we divided participants into five groups: (1) consistent-effective parenting (both caregivers apply authoritative parenting); (2) consistent-ineffective parenting (both caregivers apply non-authoritative parenting); (3) consistent-somewhat effective parenting (both caregivers apply the same parenting styles, they usually had two dominant parenting styles with one of them contain authoritative parenting); (4) inconsistent-ineffective parenting (both caregivers apply different parenting styles which were considered to be non-authoritative parenting); (5) inconsistent-somewhat effective parenting (both caregivers apply different parenting styles, with one of them contain authoritative parenting). 
The Child Adjustment and Parent Efficacy Scale (CAPES), the Intensity scale, was used to measure parents' perspectives on children's challenging behaviors. The scale consists of two dimensions: behavioral problems (24 items) and emotional problems (three items; Morawska, Sanders, Haslam, Filus, \& Fletcher, 2014). Items are rated on a 4-point scale: Not true of my child at all (0), True of my child a little or some of the time (1), True of my child quite a lot or a good part of the time (2), True of my child very much or most of the time (3) The CAPESIntensity has been translated into Indonesian by the second author and back translated. Previous studies using the Indonesian version of CAPES have indicated that the measure were reliable, $\alpha=.86$ (Sumargi et al., 2015) and $\alpha=.84$ (Haslam et al., 2018). For each participant, a total score was calculated across items with higher scores indicating higher levels of emotional and behavioral problems. In this study, an average of grandparents' and mothers' scores was used to indicate a child's challenging behavior score.

\section{Procedure}

Purposive sampling was used to select participants. Based on the eligibility criteria (that is, mothers and grandparents who had a child between the age of 2-6 years and lived together under the same roof), we recruited participants through schools (early childhood education centers and kindergartens) around Surabaya and Sidoarjo. A set of questionnaires was prepared to be distributed to mothers and grandparents with the help from schools. In addition to a set of questionnaires, participants also received an information sheet that briefly explained about the study and an informed consent form requesting their agreement to participate in the study. The participation in this study was voluntary. Those who provided consent and met the eligibility criteria were asked to complete the ques- tionnaire in their own time. The completed questionnaire were then returned to schools and collected from schools by the first author.

Of 345 returned questionnaires, 179 were excluded because parents and/or grandparents did not meet the eligibility criteria (i.e., $12.8 \%$ indicated that their child was not taken care of by grandparents, $15.6 \%$ indicated they did not live in a multigenerational family, $2.2 \%$ had a younger or older child) and the questionnaire sets were not completed properly (i.e., $46.4 \%$ returned blank questionnaires and $22.9 \%$ returned incomplete sets of questionnaires as only mothers or grandparents filled up the questionnaire). Finally, we had 73 pairs of mothers and grandparents as participants after removing pairs of caregivers whose parenting styles could not be classified (see the Measure section).

\section{Data Analysis}

A one-way ANOVA was performed to compare children's levels of challenging behavior in the five groups of parenting consistency (i.e., 10 pairs of caregivers in consistent-effective parenting, 11 pairs of caregivers in consistent-ineffective parenting, three pairs of caregivers in consistent-somewhat effective parenting, 13 pairs of caregivers in inconsistent-ineffective parenting, and 36 pairs of caregivers in inconsistent-somewhat effective parenting). Post hoc tests using Tukey's HSD were then employed for pairwise differences. Data were analyzed using SPSS version 19.0.

\section{Results}

Preliminary analyses were conducted to test if data met normality and homogeneity of variances assumptions. Table 3 shows the results of normality assumption tests using Shapiro-Wilk and Kolmogorov-Smirnov.

Table 3

The Results of Normality Assumption Tests

\begin{tabular}{lcccccc}
\hline \multirow{1}{*}{ Parenting Category } & \multicolumn{3}{c}{ Kolmogorov-Smirnov } & \multicolumn{3}{c}{ Shapiro-Wilk } \\
& Statistic & $d f$ & $p$ & Statistic & $d f$ & $p$ \\
\hline Consistent - Effective & .259 & 10 & .055 & .866 & 10 & .090 \\
Consistent - Ineffective & .130 & 11 & .200 & .949 & 11 & .636 \\
Consistent - Somewhat Effective & .335 & 3 & .000 & .857 & 3 & .260 \\
Inconsistent- Ineffective & .159 & 13 & .200 & .956 & 13 & .686 \\
Inconsistent- Somewhat Effective & .091 & 36 & .200 & .972 & 36 & .473 \\
\hline
\end{tabular}


Based on the two tests, data of parenting consistency in each group were normally distributed. The homogeneity of variance assumption was also met as measured using Levene's test; $F(4.68)=1.88, p=.124(p$ $>.05)$. Since data met the assumptions of normality and homogeneity of variance, a one-way ANOVA was performed to test differences in children's challenging behavior based on parenting consistency groups.

As seen in Table 4, there was a significant difference in children's challenging behaviors based on the parenting consistency groups, $F(4.68)=5.73, p$ $=.000(p<.05)$. Post-hoc comparative tests showed that the mean scores of children's challenging behaviors were significantly different for Group 1 (consistenteffective parenting) and Group 2 (consistent-ineffective parenting), Group 1 (consistent-effective parenting) and Group 4 (inconsistent-ineffective), and Group 4 (inconsistent-ineffective parenting) and Group 5 (inconsistentsomewhat effective parenting). Based on the mean inspection of challenging behavior, it was found that Group 1 (consistent-effective parenting) and Group 3 (consistent-somewhat-effective parenting) had the lowest levels of children's challenging behavior. By contrast, Group 4 (inconsistent-ineffective parenting) and Group 2 (consistent-ineffective parenting) had the highest levels of children's challenging behavior.

\section{Discussion}

This study investigated differences in challenging behaviors between young children in multigenerational families whose caregivers had consistent and those with inconsistent parenting. The result confirmed the hypothesis that there was a significant difference in children's challenging behaviors based on different groups of parenting consistency, particularly between those who had caregivers with consistenteffective parenting and inconsistent-ineffective parenting, caregivers with consistent-effective parenting and consistent-ineffective parenting, and caregivers with inconsistent-ineffective parenting and inconsistentsomewhat effective parenting.

The result supports the literature indicating that parenting inconsistency between caregivers is closely related to children's challenging behaviors (Barnett et al., 2012; Clarke et al., 1999). Mothers and grandparents often have different approaches in disciplining children and expressing their care (Ochiltree, 2006). Children who receive different messages from different caregivers might be confused. Differences in parenting styles can also create relationship conflicts. Barnett et al. (2012) found that a high level of conflicts between mothers and grandmothers was associated

Table 4

Mean, Standard Deviation, a One-Way ANOVA, and Post-hoc Comparisons of Children's Challenging Behavior Based on Parenting Consistency Groups

A one-way ANOVA Post-hoc Comparisons

\begin{tabular}{|c|c|c|c|c|c|c|c|c|}
\hline Groups & Mean & $S D$ & $F$ & $p$ & $\begin{array}{c}\text { Group } 2 \\
t(p)\end{array}$ & $\begin{array}{c}\text { Group } 3 \\
t(p)\end{array}$ & $\begin{array}{c}\text { Group } 4 \\
t(p)\end{array}$ & $\begin{array}{c}\text { Group } 5 \\
t(p)\end{array}$ \\
\hline 1. Consistent-Effective & 15.95 & 7.18 & 5.73 & .000 & $\begin{array}{l}-11.41^{*} \\
(.011)\end{array}$ & $\begin{array}{l}-4.38 \\
(.911)\end{array}$ & $\begin{array}{c}-12.70^{* * *} \\
(.002)\end{array}$ & $\begin{array}{l}-4.23 \\
(.551)\end{array}$ \\
\hline 2. Consistent-Ineffective & 27.36 & 4.11 & & & & $\begin{array}{l}7.03 \\
(.636)\end{array}$ & $\begin{array}{l}-1.29 \\
(.994)\end{array}$ & $\begin{array}{l}7.18 \\
(.067)\end{array}$ \\
\hline $\begin{array}{l}\text { 3. Consistent-Somewhat } \\
\text { Effective }\end{array}$ & 20.33 & 11.07 & & & & & $\begin{array}{l}-8.32 \\
(.457)\end{array}$ & $\begin{array}{c}0.15 \\
(1.000)\end{array}$ \\
\hline $\begin{array}{l}\text { 4. Inconsistent- } \\
\text { Ineffective }\end{array}$ & 28.65 & 8.46 & & & & & & $\begin{array}{c}8.47^{*} \\
(.010)\end{array}$ \\
\hline $\begin{array}{l}\text { 5. Inconsistent- } \\
\text { Somewhat Effective }\end{array}$ & 20.18 & 8.73 & & & & & & \\
\hline
\end{tabular}


with children's emotional and behavioral problems through mothers' negative parenting behaviors. Studies have shown that harsh and inconsistent parenting lead to the occurrence children's challenging behavior (Brody et al., 2003; Luxton, 2007). By contrast, consistent parenting and reasonable expectations on children's behaviors by family members were related to children's positive behaviors (Dowling, 2010).

In addition to parenting consistency, the results in this study also showed that authoritative parenting were negatively related to children's challenging behaviors. Caregivers with consistent-effective parenting, meaning that both mothers and grandparents apply authoritative parenting, had children with the lowest level of challenging behaviors. On the contrary, caregivers with inconsistent-ineffective parenting (i.e., having different parenting styles and both parenting styles were not authoritative parenting) had children with the highest level of challenging behavior. There were significant differences in children's challenging behaviors between those who had caregivers with consistent-effective parenting and those with inconsistent-ineffective parenting, as well as between those who had caregivers with consistent-effective parenting and those with consistent-ineffective parenting. This again confirms the superiority of authoritative parenting in comparison to the other parenting styles.

The findings are consistent with the results in Akhter et al.'s (2011) study. Their study with 200 pairs of parents (mothers and fathers) having children between 8-12 years old suggested that permissive and authoritarian parenting had positive correlations with children's internalizing and externalizing behavior problems, whilst authoritative parenting had negative correlations with children's internalizing and externalizing behavior problems. Specifically, authoritarian parenting of mothers and fathers significantly predicted their child's internalizing and externalizing behavior problems.

Authoritative parenting is a parenting style that encourages children to be independent. Parents with this parenting style express warmth and nurturance, but they also set limits on their child's behaviors. With this parenting style, parents often involve their child in discussion and decision making (Santrock, 2002). The literature describes authoritative parenting as the most effective parenting style as it positively impacts children's development (Lamborn et al., 1991; Steinberg et al., 1994, in Akhter et al., 2011; Querido, Warner, \& Eyberg, 2002, in Hunt, 2013). Children who are raised with authoritative parenting seem to have good relationships with their caregivers and have a positive development. This might result in a lower level of challenging behavior.

By contrast, authoritarian parenting is a restrictive, punitive parenting style in which parents exhort their child to follow their directions and to respect their work and efforts. Authoritarian parents set strict limits and do not allow their children to discuss rules (Santrock, 2002). This parenting style has been considered as the most negative parenting style as it creates anxiety, depression, and aggression in children (Baumrind \& Black, 1967, in Akhter et al., 2011). Meanwhile, permissive parenting is a style of parenting in which parents exhibit high levels of warmth and low levels of control on their children (Baumrind \& Black, 1967, in Akhter et al., 2011). With this parenting style, children show lower levels of self-control and lack of achievement (Baumrind, 1967; McCord, 1988, in Akhter et al., 2011). In other words, the use of non-authoritative parenting style, in this case authoritarian and permissive parenting, is more likely to result in child emotional and behavioral problems.

Interestingly, this study found a significant difference in children's challenging behaviors between those who had caregivers with inconsistent-ineffective and those with inconsistent-somewhat effective parenting. Children who had caregivers with inconsistent-somewhat effective parenting had lower levels of challenging behavior. Further, based on the inspection of mean challenging behavior (Table 2), there is only a small, insignificant difference in the mean scores of challenging behavior for caregivers with inconsistent-somewhat effective parenting $(M=20.18)$ and caregivers with consistent-somewhat effective parenting $(M=20.33)$. This indicates that authoritative parenting applied by at least one of caregiver might reduce children's challenging behavior. The finding supports the results from previous studies indicating positive outcomes for adolescents (e.g., greater academic competence, and lower levels of stress, depression and delinquency) who had both or either parents employ authoritative parenting (Fletcher, Steinberg, \& Sellers, 1999; Linares, Torre, Carpio, Cerezo, \& Casanova, 2014; Simons \& Conger, 2007). Thus, having one caregiver with authoritative parenting could buffer adolescents from negative consequences associated with ineffective parenting (Simons $\&$ Conger, 2007). It should be noted, however, that if both parents apply authoritative parenting, then the positive impact on children will be multiplied. Since previous studies involved only adolescents and their parents as participants, this present study has extended the findings to young children and their caregivers in multigenerational families. 


\section{Limitations and Future Studies}

This study has a number of limitations that should be considered. Firstly, this study was a cross-sectional study, therefore we could not conclude the causal relationships between parenting consistency and children's challenging behavior. Future study can investigate the impacts of parenting consistency on children's challenging behaviors using an experimental or a longitudinal design. Secondly, this study had a limited sample size. A number of prospective participants had to be removed because either mothers or grandparents did not return the questionnaire. This problem occurs partly because we did not communicate directly to parents regarding the questionnaire but sent the questionnaire sets to participants via schools. It is suggested that further study reach parents and grandparents directly through a household survey or interview. Notably, since this study classified mothers and grandparents based on their parenting consistency and effectiveness, we eliminated many participants whose parenting styles could not be classified. This also created unequal number of groups of caregivers. Despite this, we could still perform a parametric statistical test as the test assumptions were met, and therefore, we had the results based on a robust method. Finally, this study relies on questionnaires (a self-report measure) completed by mothers and grandparents. Future investigation might consider involving other child caregivers, such as fathers, relatives, or even housemaids, who might influence children's challenging behavior in order to have a comprehensive picture of the relationships between parenting consistency or parenting styles and children's challenging behaviors. Additionally, an objective measure, such as observation, might be used to capture dynamics of relationships and caregiving in a multigenerational family.

\section{Conclusions}

The literature has indicated the importance of parenting consistency between caregivers and the positive impacts of authoritative parenting on child development. This study confirms that authoritative parenting applied by both or either caregivers in multigenerational families was related to a lower level of challenging behaviors. This implies that parents and other child caregivers need to be consistent with their parenting and use authoritative parenting more frequently. It is also suggested that further research take into account both parenting consistency and effectiveness when investigating the impact of parenting on child behavior.

\section{References}

Akhter, N., Hanif, R., Tariq, N., \& Atta, M. (2011). Parenting styles as predictors of externalizing and internalizing behavior problems among children. $\mathrm{Pa}$ kistan Journal of Psychological Research, 26(1), 23-41.

Barnett, M. A., Mills-Koonce, W. R., Gustafsson, H., \& Cox, M. (2012). Mother-grandmother conflict, negative parenting, and young children's social development in multigenerational families. Family Relations, 61, 864-677. https://doi.org/10.1111/j. 1741-3729.2012.00731.x

Brody, G. H., Murry, V. M., Ge, X., Kim, S. Y., Simons, R. L. \& Gibbons, F. X. (2003). Neighborhood disadvantage moderates associations of parenting and older sibling problem attitudes and behavior with conduct disorder in African American children. Journal of Consulting and Clinical Psychology, 71, 211-222. https://doi.org/10.1037/0022-006X.71.2.211

Campbell, S. B., Shaw, D. S., \& Gilliom, M. (2000). Early externalizing behavior problems: toddlers and preschoolers at risk for later maladjustment. Development and Psychopathology, 12, 467-488. https://doi.org/10.1017/S0954579400003114

Clarke, E. J., Preston, M., Raksin, J., \& Bengtson, V. L. (1999). Types of conflicts and tensions between older parents and adult children. The Gerontologist, 39, 261-270. https://doi.org/10.1093/geront/39.3.261

Cohn, D. \& Passel, J. S. (2016). A record 60.6 million Americans live in multigenerational households. Retrieved from http://www.pewresearch.org/facttank/2016/08/11/a-record-60-6-million-americanslive-in-multigenerational-households/

Dowling, M. (2010). Young children's personal, social, \& emotional development (3rd edition). London: SAGE Publications Ltd.

Edwards, O. W. (2006). Teachers' perceptions of the emotional and behavioral functioning of children raised by grandparents. Psychology in the Schools, 43, 565-572. https://doi.org/10.1002/pits.20170

Fletcher, A. C., Steinberg, L., \& Sellers, E. B. (1999). Adolescents' well-being as a function of perceived interparental consistency. Journal of Marriage and the Family, 61, 599-610. https://doi.org/10.2307/353563

Gardner, F. \& Shaw, D. S. (2008). Behavioral problem of infancy and preschool children (0-5). In Rutter, M., Bishop, D., Pine, D., Scott, S., Stevenson, J., Taylor, E., \& Thapar, A. Rutter's Child and psychiatry (5th edition). USA: Blackwell Publishing.

Grose, M. (2011). Why consistency improves kid's behavior. Retrieved from http://www.gslc.qld.edu.au Hartina, R., Fachrina, \& Elvawati (2014). Perilaku 
anak dalam pola asuhan kakek/nenek (studi kasus di kampung Koto Rawang Nagari Lakitan Timur kecamatan Lengayang kabupaten Pesisir Selatan). Padang: Program Studi Pendidikan Sosiologi Sekolah Tinggi Keguruan dan Ilmu Kependidikan (STKIP) PGRI Sumatera Barat. Retrieved from http://download.portalgaruda.org/article.php?artic le $=317118 \&$ val6302\&title $=$ PERILAKU\% $20 \mathrm{AN}$ AK\%20DALAM\%20POLA\%20ASUHAN\%20K AKEK/NENEK\%20Studi $\% 20$ Kasus $\% 20 \mathrm{di} \% 20 \mathrm{~K}$ ampung\%20Koto\%20Rawang\%20Nagari\%20La kitan\%20Timur\%20Kecamatan\%20Lengayang\% 20Kabupaten\%20Pesisir\%20Selatan

Haslam, D., Poniman, C., Filus, A., Sumargi, A., \& Boediman, L. (2018). Parenting style, child emotion regulation and behavioral problems: The moderating role of cultural values in Australia and Indonesia. Manuscript submitted for publication.

Hoyer, W. J., Roodin, P. A., \& Rybash, J. M. (1999). Adult development and aging (4th edition). New York: McGraw-Hill.

Hunt, J. C. (2013). Associations between different parenting styles and child behavior. PCOM Psychology Dissertation. Philadelphia: Philadelphia College of Osteopathic Medicine.

Kaiser, B. \& Rasminsky, J. S. (2017). Challenging behavior in young children: Understanding, preventing, and responding effectively (4th edition). United States: Pearson.

Linares, M. C. G., Torre, M. J., Carpio, M. V., Cerezo, M. T., \& Casanova, P. F. (2014). Consistency/ inconsistency in paternal and maternal parenting styles and daily stress in adolescence. Revista de Psicodidáctica, 19, 307-325. https://doi.org/10.13 87/RevPsicodidact.7219

Liu, J. (2004). Childhood externalizing behavior: theory and implications. Journal Child Adolescent Psychiatry Nurse, 17, 93-103. https://doi.org/10.1111/j.1744-61 71.2004.tb00003.x

Luxton, D. D. (2007). The effects of inconsistent parenting on the development of uncertain self-esteem and depression vulnerability. Dissertation. Kansas: University of Kansas. Retrieved from https://www.re searchgate.net/profile/David_Luxton/publication/2944 4521_The_Effects_of_Inconsistent_Parenting_on_the _Development_of_Uncertain_Self-Esteem_and_Depr ession_Vulnerability/links/5441986e0cf2a6a049a5 bdbe.pdf

Morawska, A., Sanders, M. R., Haslam, D., Filus, A. \& Fletcher, R. (2014). Child adjustment and parent efficacy scale: Development and initial validation of a parent report measure. Australian Psychologist, 49, 241-252. https://doi.org/10.1111/ap.12057

Ochiltree, G. (2006). The changing role of grandparents. Australian Family Relationship Clearinghouse (AFRC) Briefing, 2, 1-9. Retrieved from https://aifs.gov.au/cfca/ sites/default/files/publication-documents/b2.pdf

Robinson, C. C., Mandleco, B., Olsen, S. F., \& Hart, C. H. (2001). The Parenting Styles and Dimensions Questionnaire (PSDQ). In B. F. Perlmutter, J. Touliatos, \& G. W. Holden (Eds.), Handbook of family measurement techniques: Vol. 3. Instruments \& index (pp. 319-321). Thousand Oaks: Sage.

Santrock, J. W. (2002). Life-span development: Perkembangan masa hidup (Edisi 5, jilid 1). Jakarta: Erlangga. Shimoni, R. \& Baxter, J. (2005). Working with families: perspective for early childhood professionals. Toronto: Pearson Education Canada Inc.

Simons, L. G., \& Conger, R. D. (2007). Linking motherfather differences in parenting to a typology of family parenting styles and adolescent outcomes. Journal of Family Issues, 28(2), 211-245. https://doi.org/10. 1177/0192513X06294593

Simón, C. (2011). Types of families. Retrieved from http://vwordpress.stmarys-ca.edu/ces10/files/2012/ 08/Types-of-Families-np9dwb.pdf

Sumargi, A., Sofronoff, K., \& Morawska, A. (2015). Understanding parenting practices and parents' views of parenting program: A survey among Indonesian parents residing in Indonesia and Australia. Journal of Child and Family Studies, 24, 141-160. https:// doi.org/10.1007/s10826-013-9821-3 